ARAŞTIRMA MAKALESI

\title{
Anadolu Mutfak Kültüründe Gastronomik Kimlik Unsuru Olarak Bulgur ve Bulgur Yemekleri
}

Dr. Tuba ŞAHIN ÖREN, Uşak Üniversitesi, Banaz Meslek Yüksekokulu, Uşak, e-posta: tuba.sahin@usak.edu.tr

ORCID: https://orcid.org/0000-0003-0899-9421

Dr. Öğr. Üyesi Adem ARMAN, Akdeniz Üniversitesi, Turizm Fakültesi, Antalya, e-posta: ademarman@akdeniz.edu.tr

ORCID: https://orcid.org/ 0000-0003-3999-3751

Öğr. Gör. Özkan ERDEM, Akdeniz Üniversitesi, Göynük Mutfak Sanatları Meslek Yüksekokulu, Antalya, e-posta: ozkanerdem@akdeniz.edu.tr

ORCID: https://orcid.org/ 0000-0003-0234-2218

\section{Öz}

Coğrafi yapısı, topraklarında yetişen ürünler, iklim özellikleri ile çağlar boyu üzerinde yaşayan medeniyetlerin gelenek, görenek, örf, adetleri gibi birçok değişken Anadolu'nun gastronomik kimliğini oluşturmaktadır. Anadolu'nun gastronomik kimliğini şekillendiren yegane unsurlardan biride bulgur olarak görülmektedir. Bulgur ve bulgur yemeklerinin sosyo kültürel özellikler çerçevesinde değerlendirilmesi ve unutulmaya yüz tutmuş olanlarının gün yüzüne çıkarılarak folklorik özelliklerini tespit etmek bu çalışmanın amacını oluşturmaktadır. Çalışmanın evrenini, Anadolu'da günümüzde de üretilmeye devam eden ya da unutulmaya yüz tutmuş bulgur yemekleri oluşturmaktadır. Kartopu örnekleme yöntemi aracılığı ile araştırmanın amacına uygun on beş bulgur yemeği çalışmanın örneklemini oluşturmaktadır. Nitel araştırma yönteminin kullanıldığ bu çalışmada, etnografı deseni kullanılarak çalışma desenlenmektedir. Sonuç olarak bulgur temalı yemekten on tanesinin özel günleri kutlamak, paylaşmak, neşe katmak amacıyla kullanıldığı tespit edilmiştir.

Anahtar Kelimeler: Bulgur, Bulgur Temalı Yemekler, Gastronomik Kimlik, Anadolu.

Makale Gönderme Tarihi: 25.05.2021

Makale Kabul Tarihi: 02.09.2021

\section{Önerilen Atıf:}

Şahin Ören, T., Arman, A. ve Erdem, Ö. (2021). Anadolu Mutfak Kültüründe Gastronomik Kimlik Unsuru Olarak Bulgur ve Bulgur Yemekleri, Türk Turizm Araştırmaları Dergisi, 5(3): 1961-1981.

(C) 2021 Türk Turizm Araştırmaları Dergisi. 


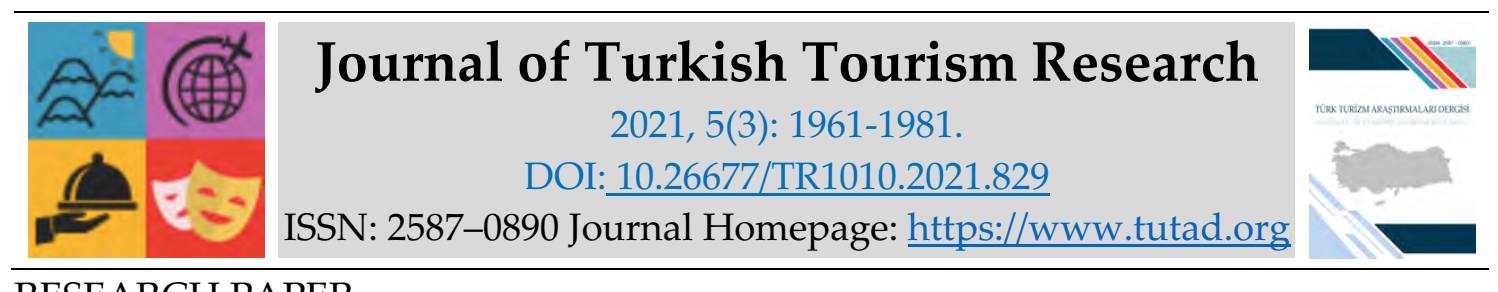

RESEARCH PAPER

\title{
Cracked Wheat and Cracked Wheat as a Gastronomic Identity Element in Anatolian Cuisine Culture
}

\author{
Dr. Tuba ŞAHIN ÖREN, Uşak University, Banaz Vocational School, Uşak, e-mail: \\ tuba.sahin@usak.edu.tr \\ ORCID: https://orcid.org/0000-0003-0899-9421
}

Assistant Prof. Dr. Adem ARMAN, Akdeniz University, Faculty of Tourism, Antalya, e-mail: ademarman@akdeniz.edu.tr

ORCID: https://orcid.org/ 0000-0003-3999-3751

Lecturer Özkan ERDEM, Akdeniz University, Göynük Culinary Arts Vocational School, Antalya, email: ozkanerdem@akdeniz.edu.tr

ORCID: https://orcid.org/ 0000-0003-0234-2218

\begin{abstract}
Many variables such as its geographical structure, products grown in Anatolia, its climate characteristics, the traditions and customs of civilizations that have lived on it for centuries constitute the gastronomic identity of Anatolia. Cracked wheat is seen as one of the only elements that shape the gastronomic identity of Anatolia. This study aims to evaluate the cracked wheat and cracked wheat dishes within the framework of socio-cultural characteristics and to determine the folkloric characteristics by revealing the forgotten ones. The universe of the study consists of cracked wheat dishes that continue to be produced in Anatolia or are about to be forgotten. The sample of the study consists of 15 cracked wheat dishes suitable for working with the snowball sampling method. In this study, the study was designed using the ethnographic pattern in which the qualitative research method was used. As a result, it was determined that ten cracked wheat -themed dishes were used to celebrate special occasions, share, and add joy.
\end{abstract}

Keywords: Cracked wheat, Cracked Wheat Themed Dishes, Gastronomic Identity, Anatolia.

Received: 25.05.2021

Accepted: 02.09 .2021

\section{Suggested Citation:}

Şahin Ören, T., Arman, A. and Erdem, Ö. (2021). Cracked Wheat and Cracked Wheat as a Gastronomic Identity Element in Anatolian Cuisine Culture, Journal of Turkish Tourism Research, 5(3): 1961-1981.

(C) 2021 Türk Turizm Araştırmaları Dergisi. 


\section{GíRiş}

Yemek, en temel fizyolojik ihtiyaçlardan biri olsa da bu eyleme psikolojik, sosyolojik ve ekonomik birçok farklı anlam yüklenmektedir (Nebioğlu, 2018). Bu nedenle zaman içerisinde her toplum kendine özgü bir yemek alışkanlığı geliştirmektedir (Beşirli, 2010). Söz konusu alışkanlıklar da o toplumun kültürü, coğrafi ve ekolojik yapısı, sosyo ekonomisi ve tarihsel süreçleri, dini ve duygusal özelliklerine göre şekil almaktadır (Samanc1, 2012; Köşker vd., 2018). Bahse konu olan bireysel ve toplumsal yönleri nedeniyle yemek, kültürel bir unsur olduğu gibi kültürün şekillenmesinde de önemli bir role sahiptir (Selimoğlu ve Gültekin, 2018). Bu nedenle de geçmişten günümüze yemeğe yüklenen anlamlar farklılık kazanmaktadır (Şanlıer, 2005; Fırat, 2014; Sevindik, 2017). Yemek; bir iletişim aracı (Abdurrezzak, 2014), toplumsal statü ve saygınlık kazanma aracı (Beşirli, 2011), bireysel veya toplumsal kimliği ifade etmede bir araç (Karaca ve Karacaoğlu, 2016; Gürhan, 2017; Çakır, 2019; Uçkan Çakır vd., 2020; Hekimoğlu, 2020), güç, iktidar ve meşruiyet sembolü (Beşirli, 2011), sosyal dönüşüm ve toplumsal örgütlenme de bir araç (Utanır, 2019), kültürün kodlandığ1, simgeselleştirildiği ve gelecek kuşaklara aktarıldığı bir kod (Beşirli, 2011; Çakır, 2019), ulusun söylemsel inşasında önemli bir faktör olarak ele alınmaktadır (Ichijo ve Ranta, 2018), Yemek, sosyal bir olgu olarak değerlendirildiğinde bireysel inançların, toplumsal özelliklerin, gelenek ve göreneklerin, kültürel ve otantik dokuların bir araya gelerek oluşturduğu toplumsal yapıyı temsil eden, kültür ve kimliğin temel yapı taşlarını oluşturma da aracı rol oynayan önemli bir etmendir (Sağır, 2012). Dolayısıyla yemek kültürü toplumları birbirinden ayıran en temel özelliklerden biri haline gelebilmektedir (Merdol, 2012).

İlgili alan yazın incelendiğinde yemek olgusunun yalnızca biyolojik bir gereklilikten öte sosyo kültürel özelliklerle birlikte değerlendirildiği görülmektedir. Yemeğin ya da daha genel bir ifadeyle gastronominin kültür ile olan bağlantısı özellikle son dönemlerde gün geçtikçe büyüyen turizm endüstrisi içerisinde kimlik duygusu gelişmiş, etnik ve kültürel değerleri keşfetmek isteyen, yöresel yemek ya da mutfakları deneyimleme arzusunda olan turistlerin sayısında önemli bir artışa neden olmuştur (Cunha, 2018). Bu bağlamda benzersiz bir mutfak deneyimi ile birlikte o yöre ya da bölgeye ait otantik ve kültürel varlıkların birlikte sunulması bir destinasyonun imajını güçlendirebileceği gibi (Hall ve Mitchell, 2005; Okumuş vd., 2007; Karim ve Chi, 2010; Güzel ve Apaydın, 2016) turistlerin seyahat motivasyonlarını da önemli ölçüde etkileyerek (Fields, 2002; Wolf, 2006) destinasyonların öncelikle tanıtılması, sonrasında ise pazarlanarak turizm aktiviteleri içerisinde kullanılmasına olanak sağlamaktadır (Boyne vd., 2002). Bu bağlamda çalışmanın amacl, Anadolu'nun gastronomik kimliğinde büyük bir öneme sahip olan bulgur ve bulgur yemeklerinin sosyo kültürel özellikler çerçevesinde değerlendirilmesi ve unutulmaya yüz tutmuş olanlarının gün yüzüne çıkarılarak folklorik özellikleri tespit etmektir.

\section{LITERATÜR TARAMASI}

Birey ya da toplumların yemeğe farklı anlamlar yüklemesi yemek tüketme amaçlarının da değişmesine neden olmuştur. Bu nedenle yemek ve turizm ilişkisi son yıllarda akademisyen ve uygulayıcıların üzerinde sıkça durduğu önemli konulardan biri haline gelmiştir. Literatürde yemek ve turizm ilişkisi bağlamında yapılan çalışmalarda yemeğin; bireylerin ya da turistlerin seyahat motivasyonlarında önemli bir çekicilik aracı (Fields, 2002; Spark vd., 2003; Kivela ve Crotts, 2006; Chang vd., 2010; Horng ve Tsai, 2010; Kim ve Eves, 2012), destinasyon tercihlerinde (Fields, 2002; Kivela ve Crotts, 2006; Kim vd., 2009), memnuniyet, şikayet ya da tekrar ziyaret gibi deneyim sonrası 
davranışsal niyetlerinde (Hall ve Sharples, 2003; Cohen ve Avieli, 2004; Kivela ve Crotts, 2006; Kim ve Eves, 2012), yemek deneyimlerinin günlük rutinin devamı olarak ya da turistlerin tatil deneyimlerinin temeli olarak değerlendirildiğinde duyulara hitap etmesi (Hjalager ve Richards, 2002; Quan ve Wang, 2004; Mak vd., 2013) nedeniyle bir destinasyonda yaşanan gastronomik deneyimlerin toplam turizm deneyiminden duyulan memnuniyeti artırdığı (Kivela ve Crotts, 2006), aynı zamanda yemeğin bir iletişim aracı gibi hem kültürün öğrenilmesi hem de aktarılmasında önemli işlevlere sahip olduğu ifade edilmektedir (Crompton ve McKay, 1997; Cohen ve Avieli, 2004; Kim vd., 2009; Stajcic, 2013; İşeri Uzunoğlu, 2019).

İlgili literatürde de görüldüğü gibi birey ya da turistlerin yemeğe ya da daha genel bir ifadeyle gastronomik ürün ve hizmetlere; deneyim, lezzet ve keşfetme gibi motivasyonlar ile yaklaşması (Uçkan Çakır vd., 2020) bu nedenle de yeni, farklı ve otantik lezzetleri tatmak istemesi (Köşker vd., 2018) özellikle son dönemlerde gastronomi turizminin birçok destinasyonun tanitım ve pazarlanmasında önemli bir role sahip olduğunu göstermektedir (Güzel, 2009). Bu bağlamda yemek deneyimi odağında belirli bölgelerle anılan turizm hareketlerinin daha etkili olduğu ifade edilirken (Hjalager ve Richards, 2002) destinasyonların ya da ülkelerin sahip oldukları mutfak kültürlerinin bir markalaşma aracı olarak kullanılabileceği ve farklılık oluşturmayı başaran mutfak kültürlerinin destinasyonlar açısından önemli bir rekabet avantajı sağlayacağı öne sürülmektedir (Kılıçhan ve Köşker, 2015; Utanır, 2019).

Söz gelimi günümüzde özellikle sosyo-ekonomik gücü yüksek olan bireylerin İtalya' nın Toscano bölgesini keçi peyniri ve şarap tatmak amacıyla ziyaret etmesi, yine İtalya'nın Portofino ve Cinque Terre yörelerine yapılan şarap ve gurme gezileri, benzer şekilde Fransa da şarap turizmi kapsamında düzenlenen; tadım gezileri, şarap festivallerine düzenlenen turlar, üzüm bağlarını görmek ve yerel kültürü öğrenmek amacıyla yapılan ziyaretler gibi birçok farklı nedenden dolayı bireyler ya da turistler bir ülke veya destinasyondaki yerel gastronomik ürünleri tanımak ya da deneyimlemek amaciyla seyahat edebilmektedirler (Çalışkan, 2013; Aslan vd., 2014; Arman ve Ak, 2021).

$\mathrm{Bu}$ bağlamda bir destinasyonu ziyaret eden bireylerin gastronomik ürün ve hizmetlerden faydalanması salt karın doyurma amacına hizmet etmemektedir. Dolayısıyla bir bölgenin gastronomik ürün ve hizmetlerinin ulusal ya da bölgesel miras ve kültür ile bağlantısı kurulduğunda o bölgenin gastronomik kimliği büyük bir önem kazanmaktadır (Çalışkan, 2013). Bu konuda yapılan erken çalışmalardan birinde Harrington (2005) gastronomik kimliği, belirli bir bölgede üretilen yiyecek ve içeceklerin ne, nasıl, neden ve ne zaman üretilip tüketildiği sorularının yanıtlandığı yiyecek ve içecek özelliklerini gösteren nitelikler olarak ifade etmektedir. Yazar bu nitelikleri kültür ve çevre olmak üzere iki başlıkta toplarken kültürün; tarih, değerler, etnik çeşitlilik, inançlar, deneme- yanılma süreçleri ve yetenekleri kapsadığını, çevrenin ise; coğrafya, iklim gibi özellikleri içine aldığını dile getirmektedir. Bu kapsamda Harrington (2005) hem kültürel özelliklerin hem de çevresel özelliklerin bir bölgenin yeme alışkanlıkları, tat tercihleri daha genel bir ifadeyle o bölgenin gastronomisi üzerinde etkili olduğunu vurgulamaktadır. Yine Harrington ve Ottenbacher (2010) da gastronomik kimliğin kültür ve çevre gibi temel özelliklerin yanı sıra sosyal duruş ve sosyo ekonomik özellikler ile de şekillenebileceğini belirtmiştir. Danhi (2005) de gastronomik kimliği oluşturan bileşenleri; coğrafya, tarih, etnik çeşitlilik, mutfak görgü kuralları, baskın tatlar ve tarifler olarak ele almaktadır. Chang ve Mak (2018) da gastronomik kimliğin en önemli özelliklerinden birinin kültürel ve çevresel özelliklerdeki otantikliğin ortaya çıkardığı anlam olduğunu ifade etmektedir. Bunlara ilave olarak Ondieki ve diğerleri de (2017) tarihsel olaylar ve etnik çeşitliliğin gastronomik kimliğin oluşum sürecine katkı sağlayan iki önemli unsur olduğunu belirtmektedir. İlgili literatür çerçevesinde Köşker 
vd., (2018) bütüncül bir yaklaşımla gastronomik kimliği bir bölgenin sahip olduğu tarihi, kültürel, coğrafi, özelliklerinin sonucu ortaya çıkan kendine özgü yeme-içme, tat, lezzet kültürü olarak tanımlamaktadır. Harrington (2005) somut ve soyut kaynaklara sahip olan bölge ya da destinasyonların gastronomik kimliğe sahip olabileceğini ifade ederken bunun aksine Fox (2007) ve Hillel ve diğerleri de (2013) söz konusu somut ve soyut kaynaklar olmadan da destinasyonların kurumsallaştırma, meşrulaştırma, tanıtma gibi faaliyetlerle gastronomik kimlik oluşturabileceğini dile getirmektedir.

Günümüzde bireylerin ya da turistlerin yeme eylemine yüklemiş olduğu anlamların farklılaşması ve yemeğin önemli bir motivasyon aracı haline gelmesi belirli bir bölgenin gastronomik kimliğinin bir yansıması olarak ortaya çıkan yerel ya da bölgesel mutfakların turistler için önemli bir çekim gücü (Cohen ve Avieli, 2004; Horng ve Tsai, 2010; Harrington ve Ottenbacher, 2010) olduğu görülmektedir. Dolayısıyla bir bölge ya da coğrafyanın sahip olduğu gastronomik kimlik ve bunun yansıması olan gastronomik ürün ve hizmetler destinasyonlara rekabet avantajı sağlayacak önemli bir farklılaşma aracı olarak kullanılabilir (Henderson, 2009; Horng ve Tsai, 2010; Harrington ve Ottenbacher, 2010). Bu kapsamda ülkeler ya da destinasyonlar gastronomik kimliklerini ya da daha genel bir ifadeyle gastronomi ve mutfak kültürlerini tanıtım materyali olarak destinasyon pazarlama faaliyetlerinde kullanabilirler (Küçükaltan, 2009).

Yemeklerin ve dolayısıyla yemek kültürlerinin, insanların kısa süreleri yer değiştirme motivasyonlarında önemli bir motivasyon kaynağı olduğu görülmektedir. Bu bağlamda, yemek kültürlerine ilişkin turizm hareketini sağlayan bu motivasyon kaynağının destinasyonlar tarafından da bir turizm ürünü olarak kullanılmaktadır. Diğer bir ifadeyle destinasyonlar, kendi bölgelerine ait yemek kültürünü turizm pazarlama aracı kullanmaktadır. Destinasyonlar için gelir getirici etkisi olan yemek kültürü gibi sosyo-kültürel unsurların ortaya çıkarılması, geliştirilmesi ve turizm ürünü olarak kullanılması bu doğrultuda önemlidir.

\section{ARAŞTIRMA YÖNTEMİ}

$\mathrm{Bu}$ çalışma da bulgur ve bulgur yemeklerinin sosyo-kültürel özellikler çerçevesinde değerlendirilmesi ve unutulmaya yüz tutmuş olanlarının gün yüzüne çıkarılarak folklorik özelliklerini tespit etmek ve bu sayede turistik bir ürün olarak ekonomik değer sağlayabileceğini göstermek bu çalışmanın amacını oluşturmaktadır. Yüzyıllardır düğünde, bayramda, cenazede kalabalık gruplar için ya da sıradan bir günde sadece öğün geçiştirmek amacıyla bulgurdan üretilen folklorik önem kazanmış bu yemeklerden bazılarını açığa çıkarmak ve unutulmamasını sağlamak çalışmanın önemini belirtmektedir.

Bu çerçevede çalışmada nitel araştırma yöntemi kullanılmıştır. Nitel araştırma yöntemleri içerisinde kuram oluşturma, durum çalışmaları, fenomenoloji, eylem araştırmaları ve etnoğrafi (kültür çalışmaları) olmak üzere birçok farklı araştırma deseni mevcuttur (Tekindal ve Uğuz Aksu, 2020). Kültür çalışmaları; ortak kültüre sahip belirli bir grubun "değer, davranış, inanç ve dilinin paylaşılan ve öğrenilen modellerini tanımlayan ve yorumlayan bir araştırma deseni (Creswell, 2020) olması nedeniyle bu araştırmada etnografı deseni kullanılmıştır. Çalışma desenine uygun olarak araştırmacılar tarafından belirlenen katılımcılarla görüşme formu üzerinden görüşmeler gerçekleştirilmiştir ve kayda alınmıştır. Konu hakkında derin bilgiye sahip olduğu düşünülen belirli bir katılımcı ile yapılan görüşme sonucunda çalışmanın devamı için konu hakkında bilgisi olduğuna inanılan başka birini tavsiye etmesine imkan sağlayan kartopu örnekleme yöntemi (Kozak, 2017) 
tercih edilmiştir. Çalışma amacına uygun kişilerin tespit edilmesi, doğru ve objektif bir şekilde veri toplanabilmesini sağlaması nedeniyle tercih edilmiştir.

Kartopu örnekleme yöntemine göre ulaşılan katılımcılarla görüşmeler, veri tekrarı gerçekleşene kadar gerçekleştirilmiştir. Toplamda on beş bulgur temalı yemeğe ulaşılmıştır. Bulgur temalı olmak üzere incelenen on beş yemek için katılımcı grupları ayrı ayrı oluşturulmuştur.

\section{Veri Toplama Aracı, Süreci ve Verilerin Analizi}

Çalışmanın görüşme formunu oluşturma aşamasında alan yazın detaylı bir şekilde incelenmiş ve araştırma soruları bu doğrultuda belirlenmiştir (Şahin Ören ve Ören, 2020; Arman ve Şahin Ören, 2020). Çalışma soruları toplamda dört temel sorudan oluşmaktadır. Çalışma soruları sonraki aşamada yarı yapılandırılmış görüşme formuna dönüştürülmüş ve anlaşılabilirliğini test etmek amacıyla yerel halktan on üç kişi ile görüşülmüştür. Görüşme formunun anlaşılabilirliğinde herhangi bir problem ile karşılaşılmamış ve çalışmanın uygulama aşamasına geçilmiştir.

Görüşmeler, katılımcıların farklı bölgelerden ve şehirlerden olması nedeniyle araştırmacıların fiziki ulaşım gerçekleştirmelerini olası kılmamıştır. Bu nedenle görüşmeler, telefonla yüz yüze, görüntülü görüşme yaparak gerçekleşmiştir. Söz konusu yemeklerin, yapımı görüntülü görüşme aracılığı ile izlenmiş ve fotoğraf ile kayda geçirmek amacıyla araştırmacılar tarafından uygulama mutfağında orijinal uygulama takip edilerek yeniden üretilmiştir. Katılımcılar ve yemeklere ilişkin görüşme süreleri ve zamanları Tablo 1'de verilmektedir.

Tablo 1. Katılımcı Görüşmeleri Süre ve Zaman Çizelgesi

\begin{tabular}{|c|c|c|c|c|c|}
\hline $\begin{array}{c}\text { Ko } \\
\text { d }\end{array}$ & Yemek Adı & $\begin{array}{c}\text { Görüşüle } \\
\text { n Kişi } \\
\text { Sayısı }\end{array}$ & Görüşmeci Kodu & $\begin{array}{c}\text { Görüşme Süresi } \\
\text { Aralığ1 }\end{array}$ & $\begin{array}{c}\text { Görüşme } \\
\text { Zamanı }\end{array}$ \\
\hline $\mathrm{B} 1$ & Haşıl Pilavı & 4 & $\mathrm{~B} 1 \mathrm{~A}, \mathrm{~B} 1 \mathrm{~B}, \mathrm{~B} 1 \mathrm{C}, \mathrm{B} 1 \mathrm{D}$ & $32-63 \mathrm{dk}$. & 01-05 Mayıs 2020 \\
\hline B2 & $\begin{array}{l}\text { Kaymaklı } \\
\text { Aş }\end{array}$ & 3 & $\mathrm{~B} 2 \mathrm{~A}, \mathrm{~B} 2 \mathrm{~B}, \mathrm{~B} 2 \mathrm{C}$ & $14-90 \mathrm{dk}$. & 05-08 Nisan 2020 \\
\hline B3 & Alacatene & 4 & B3A, B3B, B3C, B3D & $25-52 \mathrm{dk}$. & 13-15 Nisan 2020 \\
\hline $\mathrm{B} 4$ & Tirit & 3 & $\mathrm{~B} 4 \mathrm{~A}, \mathrm{~B} 4 \mathrm{~B}, \mathrm{~B} 4 \mathrm{C}$ & $34-58 \mathrm{dk}$. & 01-03 Ocak 2020 \\
\hline B5 & Batırık & 5 & $\begin{array}{c}\text { B5A, B5B, B5C, B5D, } \\
\text { B5E }\end{array}$ & $19-48 \mathrm{dk}$. & 15-20 Aralık 2020 \\
\hline B6 & Serdev & 6 & $\begin{array}{c}\text { B6A, B6B, B6C, B6D, } \\
\text { B6E, B6F }\end{array}$ & $15-57 \mathrm{dk}$ & $\begin{array}{c}\text { 01-08 Kasim } \\
2020\end{array}$ \\
\hline B7 & Sovan Aşı & 3 & B7A,B7B,B7C & $31-42 \mathrm{dk}$ & $\begin{array}{l}\text { 03-04 Temmuz } \\
2020\end{array}$ \\
\hline B8 & $\begin{array}{l}\text { Besmeç } \\
\text { Köfte }\end{array}$ & 7 & $\begin{array}{c}\mathrm{B} 8 \mathrm{~A}, \mathrm{~B} 8 \mathrm{~B}, \mathrm{~B} 8 \mathrm{C}, \mathrm{B} 8 \mathrm{D}, \mathrm{B} 8 \mathrm{E} \\
\text {,B8F,B8G }\end{array}$ & $16-92 \mathrm{dk}$. & 01-15 Eylül 2020 \\
\hline B9 & $\begin{array}{c}\text { Gurlayak } \\
\text { Taşlayacağ1 }\end{array}$ & 4 & B9A,B9B,B9C,B9D & $24-49 \mathrm{dk}$ & $\begin{array}{c}\text { 16-18 Haziran } \\
2020 \\
\end{array}$ \\
\hline B10 & $\begin{array}{c}\text { Baklalı } \\
\text { Yaprak } \\
\text { Sarması }\end{array}$ & 4 & B10A,B10B,B10C,B10D & $23-53 \mathrm{dk}$ & 22-25 Şubat 2020 \\
\hline
\end{tabular}




\begin{tabular}{|c|c|c|c|c|c|}
\hline B11 & Harla & 5 & $\begin{array}{c}\text { B11A,B11B,B11C,B11D } \\
\text {,B11E }\end{array}$ & $26-38 \mathrm{dk}$. & 06-10 Ekim 2020 \\
\hline B12 & $\begin{array}{c}\text { Kesik } \\
\text { Topalak }\end{array}$ & 3 & B12A,B12B,B12C & $33-64 \mathrm{dk}$. & $11-13$ Mart 2020 \\
\hline B13 & $\begin{array}{c}\text { Sik1c1k } \\
\text { Çorbas1 }\end{array}$ & 7 & $\begin{array}{c}\text { B13A,B13B,B13,C,B13 } \\
\text { D, B13E, B13F, B13G }\end{array}$ & $39-104 \mathrm{dk}$. & $\begin{array}{c}07-15 \text { Ağustos } \\
2020\end{array}$ \\
\hline B14 & Hüppülü & 5 & $\begin{array}{c}\text { B14A, B14B, B14C, } \\
\text { B14D, B14E }\end{array}$ & $18-42 \mathrm{dk}$. & $21-23$ Ocak 2020 \\
\hline B15 & Killotik & 7 & $\begin{array}{c}\text { B15A,B15B,B15C,B15D } \\
\text {,B15E,B15F,B15G }\end{array}$ & $58-163 \mathrm{dk}$. & $16-25$ Mart 2020 \\
\hline
\end{tabular}

Elde edilen verilerin analizinde betimleyici analiz yöntemi kullanılmıştır. Elde edilen verilere ilişkin geçerlik ve güvenirliğin sağlanması için ortaya çıkan bulgular, on beş katılımcı ve gastronomi alanında uzman üç akademisyene danışılarak onay alınmıştır. Sonraki aşamada katılımcı grupların dışından birer kişiye ulaşılarak, görüşme formundaki sorular yöneltilmiş ve araştırma bulgularına uygun sonuç alınarak çalışmanın geçerlik ve güvenirliği test edilmiştir.

Verilerin analizi sürecinde görüşmeci katılımcılara kod verilmiştir. Hem katılımcılara ilişkin ifadeleri yalın bir şekilde aktarabilmek hem de katılımcıların kişisel verilerini korumak amacıyla kodlama işlemi gerçekleştirilmiştir. Kodlama işleminde ilgili yemeğin kodunda sonra görüşmeciye ithaf edilen harf yazılmıştır. Katılımcı görüşmeciler, 1929 - 1979 arasında doğmuştur ve katılımcıların hepsi kadındır. Katılımcı görüşmecilerin hepsi ilgili yemeğin yöresinde ikamet etmektedir.

\section{Araştırmanın Amacı ve Önemi}

Anadolu mutfak kültüründe folklorik bir önem kazanmış besin maddelerinden biride bulgurdur. Bulgur, dügün, bayram, cenaze veya sıradan günlerde öğün olarak kullanılmış çorbadan, yemeğe hatta tatlıya kadar birçok yemeğin üretilmesinde kullanılmıştır. Bu çalışma, Anadolu mutfak kültürünün bütününe hitap eden bu besin öğesinin yani bulgurun folklorik değerinin ortaya çıkarılması, unutulmamasının sağlanması ve gelecek nesillere aktarılabilmesi için kayda geçirilmesi açısından önemlidir. Çalışmanın temel amacı da sosyo-kültürel açıdan öneme sahip olduğu görülen bu yemeklerin, turistik bir değer olarak görülebilmesini ve bu sayede ekonomik bir payda oluşturacağını ifade edebilmektedir. Bu amaçlar doğrultusunda çalışma hem alan yazına hem turizm sektörüne hem de gelecek nesillere aktarılmasında katkı sağlaması nedeniyle önemlidir. Çalışmanın amaçları doğrultusunda, alt amaçlar oluşturulmuştur;

- Bulgur temalı yemeğin geçmişi ile ilgili bilgi edinmek,

○ Bulgur temalı yemeğin yapılması için özel bir gün (düğün, bayram, cenaze, vb.) gerekliliği ile ilgili bilgi edinmek,

○ Bulgur temalı yemeğin içeriğini öğrenmek.

Alt amaçlar, veri toplama aracı oluşturmada belirleyici unsur olarak kullanılmaktadır. Bu nedenle katılımcılara, çalışmanın alt amaçlarına ulaşmayı sağlayabilecek sorular sorularak araştırmanın çerçevesi dışına çıkmayı engelleyecek şekilde görüşme formu yarı yapılandırılmış olarak planlanmıştır. 


\section{Evren ve Örneklem}

Çalışmanın evrenini, Anadolu mutfağında yer alan bulgur temalı yemekler oluşturmaktadır. Ancak gerçek evrenin tespit edilmesi zaman, maliyet ve çalışma evrenini içeren bütün yemeklere ulaşmanın oldukça zor olması nedeniyle örneklem oluşturulmuştur. Çalışmada öncelikli olarak kartopu örnekleme yöntemi kullanılarak araştırmacılar tarafından otuz üç katılımcı ile örneklem grubu oluşturulmuştur. Kartopu örnekleme grubu sonucunda yüz yetmiş iki aday katılımcıya ulaşılmış, çalışma konusu aktarılarak bulgur temalı yemekler hakkındaki bilgileri öğrenilmiştir. Bulgur temalı yemekler hakkındaki bilgileri yeterli görülen doksan bir aday katılımcı gönüllülük esasına göre çalışmaya davet edilmiştir. Kartopu örnekleme yöntemi ile ulaşılan doksan bir katılımcıdan yetmişi gönüllülük esasına göre çalışmaya katılmayı kabul etmiştir. Bu bağlamda çalışmanın örneklemini toplamda yetmiş katılımcı ile on beş bulgur temalı yemekten oluşturmaktadır. Tablo 2' de çalışmanın örneklemi ile ilgili bilgiler verilmektedir. Bulgur temalı söz konusu bu araştırmaya konu olan yemeklerin yöresi ve kökeni, katılımcıların görüşleri doğrultusunda ifade edilmektedir. Araştırmacılar, bulgur temalı yemeklerin yöresi ve kökeni hakkında herhangi bir görüş belirtmemektedir.

Tablo 2. Örneklem Çerçevesi

\begin{tabular}{|c|c|c|c|c|c|c|}
\hline $\begin{array}{c}\text { Ko } \\
\text { d }\end{array}$ & $\begin{array}{c}\text { Yemek } \\
\text { Adı }\end{array}$ & $\begin{array}{l}\text { Görüşülen } \\
\text { Kişi Sayısı }\end{array}$ & $\begin{array}{l}\text { Yemeğin } \\
\text { Yöresi }\end{array}$ & $\begin{array}{c}\text { Yemeğin } \\
\text { Türü }\end{array}$ & $\begin{array}{c}\text { Yemeğin } \\
\text { Folklorik } \\
\text { Değeri }\end{array}$ & $\begin{array}{c}\text { Yemeğin } \\
\text { Bilinen } \\
\text { Kökeni }\end{array}$ \\
\hline B1 & $\begin{array}{l}\text { Haşıl } \\
\text { Pilav1 }\end{array}$ & 4 & Sivas & Ana Yemek & $\begin{array}{c}\text { Düğün, } \\
\text { Davet } \\
\text { Yemeği, } \\
\text { Sünnet }\end{array}$ & $\begin{array}{l}\text { Türkmen } \\
\text { Mutfağ1 }\end{array}$ \\
\hline B2 & $\begin{array}{c}\text { Kaymaklı } \\
\text { Aş }\end{array}$ & 3 & $\begin{array}{c}\text { Afyonkarahisa } \\
\mathrm{r}\end{array}$ & Ana Yemek & Öğün & $\begin{array}{c}\text { Afyonkarahisa } \\
\text { r }\end{array}$ \\
\hline B3 & Alacatene & 4 & Uşak & Ana Yemek & Öğün & Uşak \\
\hline B4 & Tirit & 3 & Diyarbakır & Ana Yemek & $\begin{array}{l}\text { Davet } \\
\text { Yemeği, } \\
\text { Düğün }\end{array}$ & Diyarbakır \\
\hline B5 & Batırık & 5 & Karaman & Ana Yemek & $\begin{array}{c}\text { Davet } \\
\text { Yemeği }\end{array}$ & $\begin{array}{c}\text { Karaman/Erme } \\
\text { nek } \\
\end{array}$ \\
\hline B6 & Serdev & 6 & Mardin & Ana Yemek & $\begin{array}{l}\text { “Zev", } \\
\text { Davet } \\
\text { Yemeği, } \\
\text { Düğün, } \\
\text { Öğün }\end{array}$ & Mardin \\
\hline B7 & Sovan Aş1 & 3 & Balıkesir & Ana Yemek & Öğün & Balıkesir \\
\hline B8 & $\begin{array}{l}\text { Besmeç } \\
\text { Köfte }\end{array}$ & 7 & Kırıkkale & Ana Yemek & $\begin{array}{c}\text { Davet } \\
\text { Yemeği, } \\
\text { Düğün, } \\
\text { Kına, } \\
\text { Gelin } \\
\text { Alma }\end{array}$ & Kırıkkale \\
\hline
\end{tabular}




\begin{tabular}{|c|c|c|c|c|c|c|}
\hline B9 & $\begin{array}{c}\text { Gurlayak } \\
\text { Taşlayaca } \\
\text { ğ1 }\end{array}$ & 4 & Çanakkale & Ana Yemek & Öğün & $\begin{array}{c}\text { Muhacir } \\
\text { (Göçmen) }\end{array}$ \\
\hline B10 & $\begin{array}{c}\text { Baklalı } \\
\text { Yaprak } \\
\text { Sarması }\end{array}$ & 4 & Samsun & $\begin{array}{c}\text { Ana } \\
\text { Yemek/Başlan } \\
\text { g1ç }\end{array}$ & $\begin{array}{c}\text { Davet } \\
\text { Yemeği, } \\
\text { Bayram }\end{array}$ & Samsun \\
\hline B11 & Harla & 5 & Doğu Anadolu & Ana Yemek & $\begin{array}{c}\text { Lohusa } \\
\text { Yemeği }\end{array}$ & Doğu Anadolu \\
\hline B12 & $\begin{array}{c}\text { Kesik } \\
\text { Topalak }\end{array}$ & 3 & İç Ege & Ana Yemek & Öğün & İç Ege \\
\hline B13 & $\begin{array}{c}\text { Sikıc1k } \\
\text { Çorbası }\end{array}$ & 7 & Kütahya & Çorba & $\begin{array}{c}\text { Davet } \\
\text { Yemeği, } \\
\text { Ramazan, } \\
\text { Bayram }\end{array}$ & Kütahya \\
\hline B14 & $\begin{array}{c}\text { Hüppülü } \\
\text { Bung }\end{array}$ & 5 & Zonguldak & Tatlı & $\begin{array}{c}\text { Bayram, } \\
\text { Dini } \\
\text { Toplantı }\end{array}$ & Zonguldak \\
\hline Killotik & 7 & Adiyaman & Ana Yemek & Düğün & Adıyaman \\
\hline
\end{tabular}

Örneklem çerçevesinde yemeğin yöresi belirtilirken katılımcı görüşleri dikkate alınmıştır. Araştırmacılar, çalışmanın objektifliğine zarar vermemek adına herhangi bir görüş belirtmemiş, yönlendirici olabilecek herhangi bir soru sorulmamıştır. Katılımcıların görüşleri, yemeklerin yöreleri ile genel durumu ortaya koymaktadır.

\section{BULGULAR ve YORUM}

Anadolu mutfak kültüründe folklorik bir öneme sahip besin maddesi olarak bulgur temalı yemeklerin araştırıldığı bu çalışmada, toplamda on beş bulgur temalı yemek incelenmektedir. Gizilde kalmış verilere ulaşabilmek amacıyla nitel araştırma yöntemleri kullanılarak tasarlanan bu çalışmadan elde edilen veriler, betimsel analiz yöntemiyle analiz edilmiştir. Bu çerçevede, bulgular; a) Bulgur temalı yemeklerin geçmişleri, b) Bulgur temalı yemeklerin özel bir anlam ifade edip etmediği ve c) Bulgur temalı yemeklerin içeriği bakımından değerlendirilmektedir.

\section{Bulgur Temalı Yemeklerin Geçmişi ile İlgili Elde Edilen Bilgiler ve Yorumu}

Katılımcılara, bulgur temalı ilgili yemeğin geçmişi ile ilgili bilgi edinmek amacıyla sorular sorulmuştur. Bulgur temalı ilgili yemek ve verilen cevaba ilişkin bilgiler Tablo 3' de gösterilmektedir. Veriler analiz edilirken "Geçmiş" ile ilgili olduğu saptanan ifadeler kendi aralarında toplanarak kodlanmıştır. 
Tablo 3. Bulgur Temalı Yemeğin Geçmişi ile İlgili Bilgiler

\begin{tabular}{|c|c|c|}
\hline $\begin{array}{c}\text { Yemeğin } \\
\text { Kodu }\end{array}$ & $\begin{array}{l}\text { Yemeğin } \\
\text { Adı }\end{array}$ & İfadeler \\
\hline \multirow[b]{2}{*}{ B1 } & \multirow[b]{2}{*}{ Haşıl Pilavı } & Nenelerimizden çok gördük, yavrum. Misafiri olanın evinde eti yoksa haşıl yapardı. \\
\hline & & $\begin{array}{l}\text { Eskiden hiçbir evin haşıl tarifi istediğini hatırlamazdım sanki hepsi anadan doğma } \\
\text { biliyordu. }\end{array}$ \\
\hline \multirow{2}{*}{$\mathrm{B} 2$} & \multirow{2}{*}{$\begin{array}{l}\text { Kaymakl1 } \\
\text { Aş }\end{array}$} & $\begin{array}{l}\text { Önceden çok çeşit yemek yoktu. Bulduklarımızla doymaya çalışırdık. Sabah katık olmadı̆̆ } ı \\
\text { için kaymaklı aş yapar yerdik. }\end{array}$ \\
\hline & & $\begin{array}{l}\text { Eskiden büyüklerimiz kaymaklı aş yaptı̆̆ında sevinirdik. Her gün öğ̈̈̈lerde bulgur aşı } \\
\text { yerdik. Kaymağa düşkün olduğumuz için bulgurla pişirildiğinde farklılık olurdu. }\end{array}$ \\
\hline \multirow[b]{2}{*}{ B3 } & \multirow[b]{2}{*}{ Alacatene } & $\begin{array}{l}\text { Eskiden yokluk zamanlarında insanlar evde ne varsa onu pişirirlerdi, bizde de en çok yeşil } \\
\text { mercimek, bulgur olurdu. }\end{array}$ \\
\hline & & $\begin{array}{l}\text { Babaannem, babaannesinden öğrenmiş. Sende yaparsın torunlarına derdi. Ben pek } \\
\text { yapmadım, zamane çocukları farklı şimdi her şey var, kızım. Bizim zamanımız da bol } \\
\text { değildi, yokluk vardı. }\end{array}$ \\
\hline \multirow{3}{*}{ B4 } & \multirow{3}{*}{ Tirit } & $\begin{array}{l}\text { Daha küçükken öğrenmiştim bu yemeği yapmayı sonraları kendi çocuklarıma yapmaya } \\
\text { başladım ve gelinlerime öğrettim onlar da kendi ailelerine yapıyorlar. }\end{array}$ \\
\hline & & $\begin{array}{l}\text { Tirit adı birçok yemek için kullanılıyor bunun içinde pirinç olanı da var ekmekle yapılan } \\
\text { etli olanı da var ama bizim Diyarbakır Ergani yöresinin Tiriti bu şekilde yapılıyor. }\end{array}$ \\
\hline & & $\begin{array}{l}\text { Önceleri yokluktan doyurucu olsun diye yapılıyordu, zamanla düğ̈̈nlerde, davetlerde } \\
\text { yapmaya başladılar. }\end{array}$ \\
\hline \multirow[b]{2}{*}{ B5 } & \multirow[b]{2}{*}{ Batırık } & $\begin{array}{l}\text { Eve misafir geldiğinde yapardık, özel bir yemekti, Batırık. Benim bildiğim herkes yapardı, } \\
\text { onlarda eskilerden görmüştür. }\end{array}$ \\
\hline & & $\begin{array}{l}\text { Annemin annesi, ona da annesi öğretmiştir, bu kadar yemek mi vardı. Bildiğimiz } \\
\text { yemekleri hep yaşlılarımızdan öğrendik, şimdiki gelinler, telefona bakıp yapıyor çeşit çeşit. } \\
\text { Bizim yemeklere sıra gelmez, unutulur gider. }\end{array}$ \\
\hline \multirow[t]{2}{*}{ B6 } & \multirow[t]{2}{*}{ Serdev } & $\begin{array}{l}\text { Eskiden küçükken yapardık hatta bazen pilavına kavurma ekleyip sıcak yemek olarak da } \\
\text { tüketirdik. }\end{array}$ \\
\hline & & Yoksul olduğumuz için yapardık. \\
\hline \multirow[t]{2}{*}{ B7 } & \multirow[t]{2}{*}{ Sovan Aşı } & $\begin{array}{l}\text { Evvel pazara bile doğru düzgün gidemezdik bu nedenle bahçede yetişen sovanları toplar. } \\
\text { Kendi öğ̈̈tttüğ̈̈müz bulguru ve kendi yaptığımız domates salçasını ayrıca tereyağını } \\
\text { kullanırdık. }\end{array}$ \\
\hline & & $\begin{array}{l}\text { En çok bulabildiğimiz salça ve tereyağı olduğundan mıdır bilinmez çok yă̆lı ve salçalı } \\
\text { yerdik. }\end{array}$ \\
\hline \multirow{4}{*}{ B8 } & \multirow{4}{*}{$\begin{array}{l}\text { Besmeç } \\
\text { Köfte }\end{array}$} & $\begin{array}{l}\text { Çok uzuun zamanlardan beri yapılırmış, bir ara unutulduktan sonra tekrar yapılmaya } \\
\text { başlamış. }\end{array}$ \\
\hline & & $\begin{array}{l}\text { Annemden öğrendim, önceden bunu yaparken kırmızı etten başka et kullanmazdı annem, } \\
\text { öyle daha güzel olurmuş. Annemin, annesinin, annesi eski yemektir. }\end{array}$ \\
\hline & & Dedemden öğrendik biz bunu köy odalarında ă̆ır misafirlere yaparlarmış \\
\hline & & Ben düğ̈̈̈nlerde göre göre öğrendim. Bütün gelinler toplaşır misafirlere yapardık \\
\hline \multirow{2}{*}{ B9 } & \multirow{2}{*}{$\begin{array}{l}\text { Gurlayak } \\
\text { Taşlayacağ } 1\end{array}$} & $\begin{array}{l}\text { Ben küçükken Gurlayacak Taşlayacă̆ı annem yapardı, şimdilerde aklıma geldikçe } \\
\text { yaparım. }\end{array}$ \\
\hline & & $\begin{array}{l}\text { Eski zamanlardan, çok eski zamanlardan yapılır. Eski zamanlarda tarlalarımızda işçiler } \\
\text { çalışırdı. Karın doyuracaktık, işçi çalıştırırdık. }\end{array}$ \\
\hline \multirow{2}{*}{ B10 } & \multirow{2}{*}{$\begin{array}{l}\text { Baklalı } \\
\text { Yaprak } \\
\text { Sarması }\end{array}$} & $\begin{array}{l}\text { Bizim zamanımızda çocuklarımıza güzel şeyler yapmak için pirincin olmadı̆̆ı yerde } \\
\text { bulgur kullanırdık }\end{array}$ \\
\hline & & $\begin{array}{l}\text { O zamanlar çok yokluk vardı der anam, et bulunmazdı et tadı için baharatlar kullanırdık } \\
\text { der anam. }\end{array}$ \\
\hline B11 & & Şimdilerde gençler pek ilgilenmezler ama biz küçükken annemizden öğrenmiştik. \\
\hline
\end{tabular}


Eskiden değerli bir yemekti, zamanla biz de pek yapmamaya başladık.

\begin{tabular}{|c|c|c|}
\hline \multirow[b]{2}{*}{ B12 } & \multirow[b]{2}{*}{$\begin{array}{l}\text { Kesik } \\
\text { Topalak }\end{array}$} & Topalak yapmayı annemden, anneannemden öğrendim \\
\hline & & $\begin{array}{l}\text { Yokluktan et bulmakta zorlanırmışız eskiden, bu yüzden etsiz yaparız. Damă̆ımız } \\
\text { alıştığından mıdır etli olanı pek sevmeyiz }\end{array}$ \\
\hline \multirow[t]{2}{*}{ B13 } & \multirow{2}{*}{$\begin{array}{l}\text { Sikıcık } \\
\text { Çorbası }\end{array}$} & $\begin{array}{l}\text { Ben kendimi bildim bileli bilirim bu yemeği, senelerdir yaparız. Annem de yapardı benim } \\
\text { ananemde. Muhacirler pek bilmezdi ama şimdi onlar da biliyor. Burada yaşayan herkes } \\
\text { eninde sonunda öğrenir bu yemeği. Biz "Biliguli" deriz buna. }\end{array}$ \\
\hline & & $\begin{array}{l}\text { Ben annemden öğrendim. Köyde hep yapıyorduk, hala arada bir yaparız. Tarhanayı da } \\
\text { kendimiz yapıyorduk. Kütahyalıların çok yaptığı yemek }\end{array}$ \\
\hline \multirow{2}{*}{ B14 } & \multirow{2}{*}{ Hüppülü } & Yemeğin yapılışı üç kuşak öncesine kadar gider ama artık çok sık yapılmıyor. \\
\hline & & Tatlı olarak yendiği için yemeğin sonunda sunulurdu. \\
\hline \multirow[t]{2}{*}{ B15 } & \multirow[t]{2}{*}{ Killotik } & $\begin{array}{l}\text { Ben kardeşlerimle toplanır anneme yardım ederdim. Yapınca çok büyük kazanlarda yapar, } \\
\text { birkaç gün bol bol yerdik. Şimdi de benim kızlarım bana yardım ediyor yine beraberce } \\
\text { yapıyoruz. Onlar da kızlarına öğretecek inşallah }\end{array}$ \\
\hline & & $\begin{array}{l}\text { Ananem şimdiki gibi özenmezdi topalakları sadece sıkıp bırakırdı ben kaynanamdan } \\
\text { yuvarlayarak yapmayı öğrendim böyle yapıyorum }\end{array}$ \\
\hline
\end{tabular}

Tablo 3' de bulgur temalı yemeklerin hepsinin birkaç nesil geriye gittiği görülmektedir. Katılımcıların ifadeleri doğrultusunda, bulgur temalı yemeklerin Anadolu mutfak kültürü içinde yeri olduğu geçmişten günümüze kadar nesiller aracılığı ile aktarıldığı görülmektedir. Bulgur temalı yemeklerin Anadolu mutfak kültürü içindeki yeri ve önemi ise Tablo 4'de gösterilmektedir.

Bulgur temalı yemeklerin, nesiller boyunca aktarıldığı, özel günlere anlam katmak, paylaşmak, duyguları aktarmak amacıyla kullanıldığı Tablo 4'de görülmektedir. Anadolu mutfak kültüründe sadece karın doyurmak için bulgur temalı yemeklerin kullanılmadığı, düğün, kına, bayram, ramazan, lohusalık gibi özel anlarda da kullanıldığı belirlenmektedir.

Tablo 4. Bulgur Temalı Yemeğin Özel Günlerde Hazırlanması ile İlgili Elde Edilen Bilgiler

\begin{tabular}{|c|c|c|}
\hline $\begin{array}{l}\text { Yemeğin } \\
\text { Kodu }\end{array}$ & $\begin{array}{l}\text { Yemeğin } \\
\text { Adı }\end{array}$ & Ífadeler \\
\hline \multirow{3}{*}{ B1 } & \multirow{3}{*}{$\begin{array}{l}\text { Haşıl } \\
\text { Pilavı }\end{array}$} & Özel bir yeri vardl; sevdiği, seveni, misafiri gelen haşıl yapardı. \\
\hline & & $\begin{array}{l}\text { Zamanında nenem hamile olanlara yapıp götürürdü Besleyici olduğundan o da } \\
\text { bir adet gibi olmuş. Neden hamile olanlara götürüyorsun dediğimizde bize hep } \\
\text { misafir var derdi. }\end{array}$ \\
\hline & & $\begin{array}{l}\text { Bizim zamanımızda misafir gelir, dü̆̆̈̈̈ olur, sünnet olsun kesin yapılırdı. } \\
\text { Şimdi normalde yapıyorlar, unutmadılar. }\end{array}$ \\
\hline \multirow[t]{2}{*}{ B4 } & \multirow[t]{2}{*}{ Tirit } & $\begin{array}{l}\text { Düğ̈̈̈nlerde büyük kazanlarda erkekler tarafindan yapılır asma yapră̆ı ile } \\
\text { dağıtılırdı asma yaprağının ve yemeğin içine konulan sumak suyunun verdiği } \\
\text { ekşilik çok güzel olurdu. }\end{array}$ \\
\hline & & $\begin{array}{l}\text { Benim zamanımda annem bu yemeği günlerde yapardı. Mahalledeki kadınlar eve } \\
\text { gelirdi ve şu anki kısır yerine bu yemek yapılırdı hep beraber yenilirdi. }\end{array}$ \\
\hline \multirow{2}{*}{ B5 } & \multirow{2}{*}{ Batırık } & Misafir dendiğinde akla hemen batırık gelirdi. \\
\hline & & Bir evde misafir varsa üç öğ̈̈̈nden birisi batırıktı. \\
\hline \multirow{2}{*}{ B6 } & \multirow{2}{*}{ Serdev } & Bayram kışa denk gelince bayram günü pişirilirdi \\
\hline & & Küçükken hatırlıyorum kışın düğ̈̈̈nlerde yapılırdı. \\
\hline
\end{tabular}


Bizim zamanımızda "Zev" adını verdiğimiz özel bir tarih vardı genelde bu tarihte köyün zenginleri bir hayvan keserler etinden kavurma yapar Serdev'in pilavına karıştırılır ve bütün köy halkı beraber yerdik.

Eve yabancı ağır misafir geldiğinde yapardık.

Kınadan bir gün önce erkek tarafları yapardı kutlama olduğunu belli etmek için.

Gelin alıyorlar kolay mı erkek tarafı yapardı ondan. Ama şimdi kız tarafları da yapar.

B8 Besmeç O gün erkek evine giden misafirler tavuklarnyla beraber gider. Herkes o gün Köfte köftenin yapılacağını bilir.

Kurban Bayramı'nda da çok yapılır, bütün aile toplaşır gençlerin eline veririz tokmakları. Biri yoruldukça diğeri vurur tokmağı.

Köy odalarına önemli insanlar gelecekse o zamanlarda da yapılırmış Bayramlarda sürekli sofra kurulurdu Karadeniz kültüründe her misafir

Baklalı geldiğinde sofra illaki kurulur o yüzden her sofrada yer alırdl.

B10 Yaprak Misafirlerimiz gelince hep sofrada olurdu.

Sarması Çok insanl her sofrada bulunuyordu sonralardan ziyafet yemeklerine koyulmaya başlandı tabi, eskiden yokluk içinde yapılırdı özel günlerde.

\begin{tabular}{lll}
\hline \multirow{3}{*}{ B11 Harla } & Doğum yapan kadına götürüllürdü. \\
& $\begin{array}{l}\text { Sütü olsun diye, yeni doğum yapan kadına götürü̈lür yedilirdi. Bi kaşıkta olsun } \\
\text { yerdi. }\end{array}$
\end{tabular}

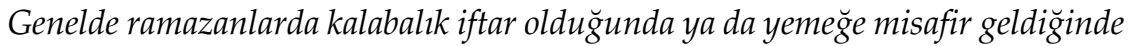
yapardik.

Mahallede bir şey olunca gün olur, doğum olur toplanılacă̆ı zaman yapılır

B13 Sikıcik genelde.

Çorbası En çok kadınlar gün yapınca yapılıyordu. Bir de ramazanda ya da bayram yemeklerinde toplanılacă̆ı zaman yapılıyordu çokça.

Ne zaman kalabalık olunsa, misafir gelse akşam yemeğine yapılırdı. Hem çabuk oluyor hem de seviyor herkes Kur'anlar da yapilırdi.

\begin{tabular}{|c|c|c|}
\hline \multirow[t]{2}{*}{ B14 } & \multirow[t]{2}{*}{ Hüppülü } & Bayramlarda muhakkak yapılır, gelen misafire yemek sonunda ikram edilirdi \\
\hline & & Annem her bayram da yapardl \\
\hline \multirow[t]{2}{*}{ B15 } & \multirow[t]{2}{*}{ Killotik } & $\begin{array}{l}\text { Düğ̈̈̈nlerde yapılırdı ama her dü̈̆̈̈nde değildi. Zenginler, ağalar yaptırırdı. } \\
\text { Benim dü̈̆̈̈̈nümde yapılmadı. }\end{array}$ \\
\hline & & Zengin olanların dü̆g̈̈nünde olurdu, genelde. Severdik, öyle düğünle \\
\hline
\end{tabular}

\section{Bulgur Temalı Yemeklerin Malzeme Bilgisi}

Katılımcıların tamamından çalışma konusunu içeren bulgur temalı yemeğin üretilebilmesi için gereken malzeme bilgisi alınarak verilen bilgilerde değişiklik olup olmadığı kontrol edilmiştir. Bu durum üzerinde çalışllan bulgur temalı yemeklerin tariflerinin, bölgeye özgü, orijinal ve değişmediğini gösteren önemli bir bulgu olarak kabul edilmektedir. Çalışmanın güvenirliği ve geçerliğini sağlamak amacıyla bu kontroller yapılarak üzerinde çalışılan yemekle ilgili verilen tarifler arasında herhangi bir farklılık tespit edilmemiştir. Tablo 5' te malzeme bilgileri yansıtılmaktadır. 
Tablo 5'te bulgur temalı araştırma konusu içerisinde incelenen on beş yemeğin malzeme bilgisi ve görselleri gösterilmektedir. Yemeklerin tamamı bulguru kendisine tema edindiği görülmektedir. Ancak servis edilme şekilleri ve hazırlanış şekilleri benzerlik göstermemektedir.

Tablo 5. Bulgur Temalı Yemeklerin Malzeme Bilgisi ve Görsel Gösterimi

\begin{tabular}{|c|c|c|}
\hline Yemeğin Adı & Yemeğin Malzeme Bilgisi & Görsel Gösterimi \\
\hline Haşıl Pilavı & $\begin{array}{ll}\text { - } & \text { Pilavlık Bulgur } \\
\text { - } & \text { Süzme Yoğurt } \\
\text { - } & \text { Su } \\
\text { - } & \text { Tuz } \\
\text { - } & \text { Tereyağı } \\
\text { - } & \text { Pekmez (isteğe göre) }\end{array}$ & \\
\hline Kaymaklı Aş & $\begin{array}{ll}\text { - } & \text { Bulgur } \\
\text { - } & \text { Kaymak } \\
\text { - } & \text { Ayçiçek Yağ } \\
\text { - } & \text { Su } \\
\text { - } & \text { Tuz }\end{array}$ & \\
\hline Tirit & $\begin{array}{ll}\text { - } & \text { Kavurma } \\
\text { - } & \text { Tane sumak } \\
\text { - } & \text { Kuru soğan } \\
\text { - } & \text { Yeşil soğan } \\
\text { - } & \text { Maydanoz } \\
\text { - } & \text { Bulgur } \\
\text { - } & \text { Domates salçası } \\
\text { - } & \text { Biber salçası } \\
\text { - } & \text { Kurutulmuş biber }\end{array}$ & \\
\hline Batırık & $\begin{array}{ll}\text { - } & \text { İnce Bulgur } \\
\text { - } & \text { Ceviz } \\
\text { - } & \text { Kuru Soğan } \\
\text { - } & \text { Domates } \\
\text { - } & \text { Maydanoz } \\
\text { - } & \text { Taze Soğan } \\
\text { - } & \text { Kuru Fesleğen } \\
\text { - } & \text { Tuz } \\
\text { - } & \text { Su } \\
\end{array}$ & \\
\hline
\end{tabular}




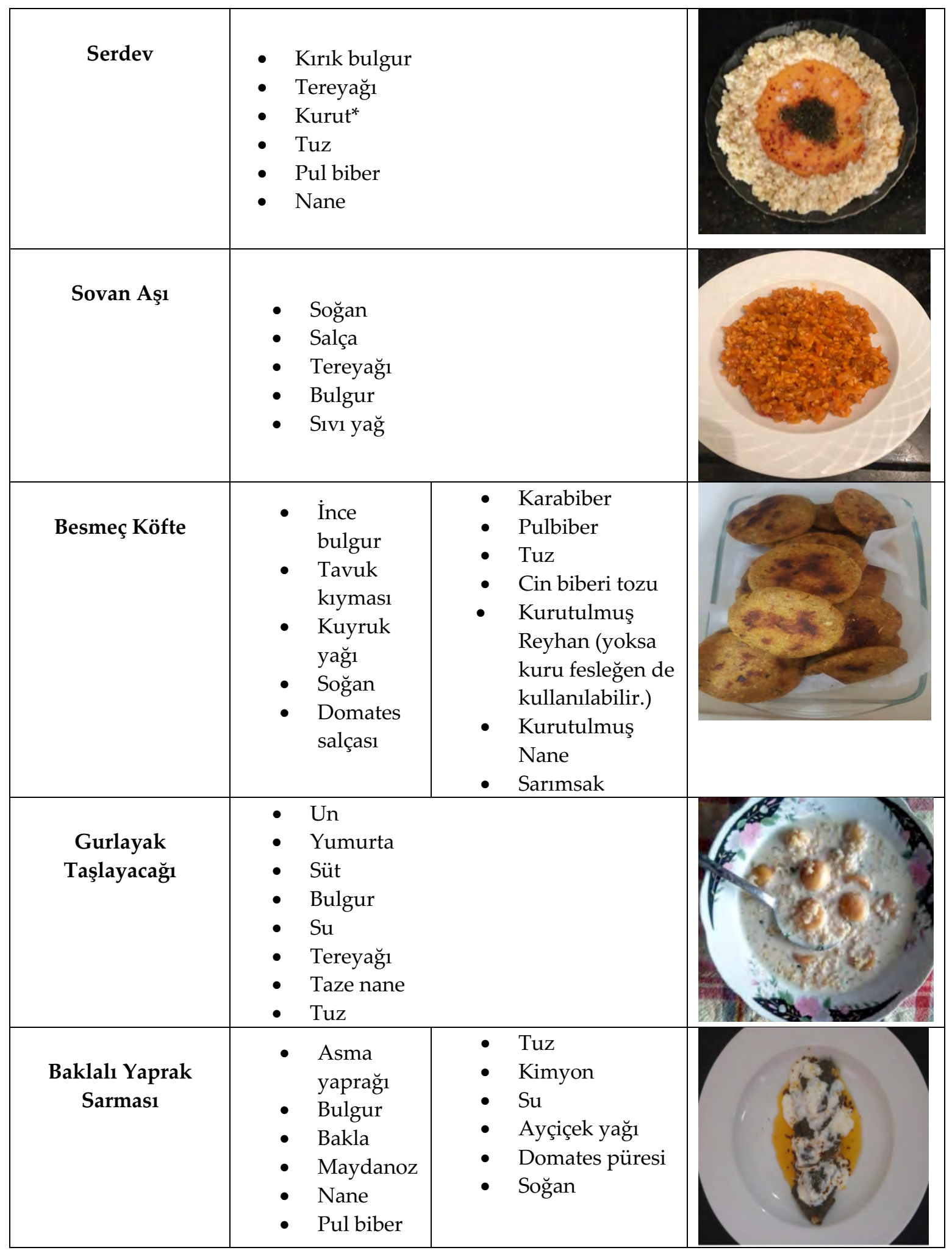




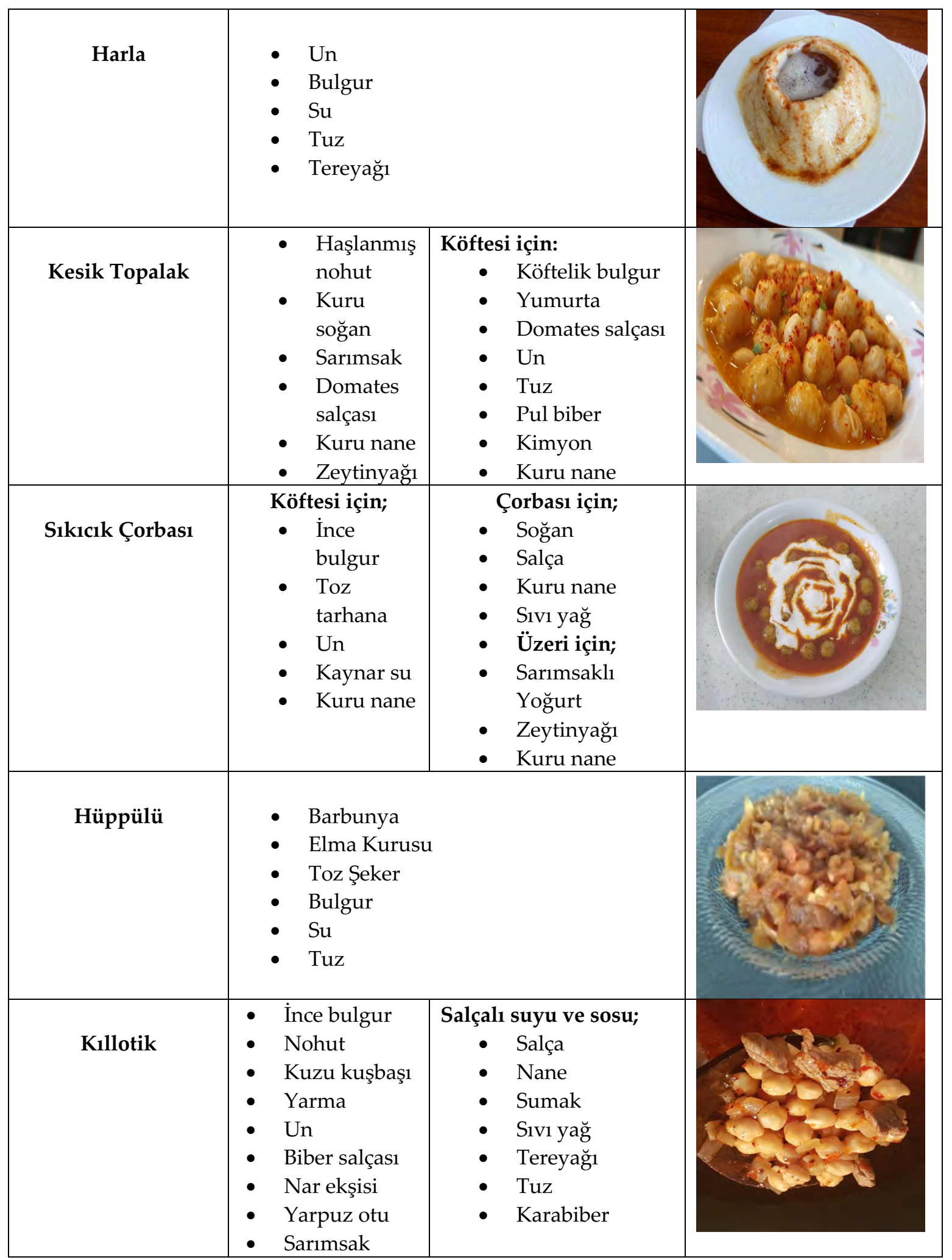




\begin{tabular}{|l|l|l|}
\hline Alacatene & - Yeşil mercimek \\
- Bulgur \\
- Kuru soğan \\
- Domates salçası \\
- Sivı yağ \\
- Sicak su \\
- Tuz
\end{tabular}

\section{SONUÇ ve ÖNERİLER}

Bulgur, Anadolu mutfağını temsil eden besin önemli maddelerinden biridir. Anadolu mutfak kültürü denilince akla gelen ilk besin maddelerinden olan bulgur ve bulgurlu yemeklerin genellikle yokluktan ortaya çıktığı düşünülmektedir. Ancak bu çalışma sonucunda görülmüştür ki, bulgurun her ne kadar ögünleri geçiştirmek için kullanıldığı düşünülse de Anadolu halkı yüzyıllardır dügün, bayram, misafir ağırlamak amacıyla düzenlenen davet yemekleri, asker uğurlama, dini toplantılar, ramazan, lohusalık gibi özel günleri ve anları da nitelendirebilmek için bulgur temalı yemekleri kullanmaktadır. Bulgur, Anadolu'da oldukça kolay elde edilebilen bir besin maddesi olsa da Anadolu halkı özel ve önemli günlerini, anlarını anlamlandırmak için hazırladığı yemeklere temel besin maddesi olarak kullanmaktadır.

Çalışma kapsamına alınan on beş bulgur temalı yemekten on tanesinin özel günleri kutlamak, paylaşmak, neşe katmak amacıyla kullanıldığı tespit edilmektedir. Aynı zamanda düğün gibi kutlamalarda erkek evinden kesinlikle beklenen ve bu sayede sembolik hale getirilmiş olan bulgur temalı yemeğin (Besmeç Köfte) bile olduğu görülmektedir. Bayramlarda kesinlikle hazırlanan "Baklalı Yaprak Sarması", "Hüppülü" sembolik hale gelen bulgur temalı yemek olarak belirlenmektedir. Birliği, beraberliği ve paylaşmayı ifade eden özel günlerden biri olan "Zev" geleneğinde hazırlanan "Serdev" yine sembolik bir ifade taşımaktadır.

Günümüzde yemek yeme eylemine yüklenen anlamların farklılaşmasıyla beraber belirli destinasyonlardaki yiyecek ve içeceklerin, turistleri o bölgeyi tercih etmede önemli bir çekicilik kaynağ1 olduğu görülmektedir (Cohen ve Avieli, 2004; Horng ve Tsai, 2010; Harrington ve Ottenbacher, 2010). Bu nedenle destinasyonların mutfak ile ilgili miras ve kültürünün, bir turizm ürünü olarak ele alınması ve turistlerin deneyimlerine sunulması büyük önem arz etmektedir (Şahin ve Ünver, 2015). Söz gelimi Hjalager (2004) gastronomik ürünlerin bir turizm ürünü olarak değerlendirilmesinde takip edilmesi gereken süreçleri; yerel gelişim aşaması, yatay gelişim aşaması, dikey gelişim aşaması ve çapraz gelişim aşaması olarak ele almıştır. Nebioğlu (2017) ise Alanya bölgesine ait gastronomik ürünlerin turistik bir ürün olarak değerlendirilebilmesi amaciyla bahse konu aşamaları dikkate alarak yapmış olduğu araştırmasında; bölge ürünlerinin genellikle ilk iki aşamada olduğunu yani, yerel pazarlarda satıldığı ya da ambalaj veya kutu içerisinde hediyelik vb. olarak kullanıldığını belirtmiştir. Köşker vd., (2018) yapmış oldukları çalışmada Ereğli bölgesine ait Osmanlı çileğinin coğrafi ve kültürel özellikleri dolayısıyla gastronomik kimlik unsuru olarak değerlendirilmesi gerektiğini, bunun için de festival, sosyal medya, görsel medya vb. gibi çeşitli araçların kullanılması gerektiğini ifade etmişlerdir. Çalışmada Osmanlı çileğinin gastronomik kimlik unsuru ele alınması ve bir turizm ürünü olarak değerlendirilmesinin bölgenin marka değerine olumlu katkı sağlayacağı vurgulanmıştır. 
Elde edilen bulgular neticesinde bulgurun ve bulgur yemeklerinin hem coğrafi özellikler hem de sosyo kültürel nedenlerden dolayı Anadolu mutfak kültüründe önemli bir yere sahip olduğu ve nesilden nesile aktarıldığı görülmektedir. Bu nedenle gastronomik kimliğin oluşum süreci de düşünüldügünde ve konuyla ilgili literatür incelendiğinde bulgur Anadolu mutfak kültürünü temsil eden önemli bir gastronomik kimlik ögesi olduğu söylenebilir. Bu kapsamda ileride Anadolu'da bulgur temalı unutulmaya yüz tutmuş yemeklerin ortaya çıkarılması için çalışmalar yapılabilir. Bulgur temalı yemeklerin coğrafi işaret ile tescillendirilerek hem Anadolu gastronomik kimliğinin korunmasına hem de bir turizm ürünü olarak kullanılmasına fayda sağlamak amaciyla akademik çalışmalar yürütülebilir. Turizm sektöründe yer alan yiyecek içecek işletmeleri tarafından bulgur temalı yemekler kullanılarak gastronomik çeşitlilik arttırmaya yönelik çalışmalar yapılabilir.

\section{KAYNAKÇA}

Abdurrezzak, A. O. (2014). İşlevsel Teori Bağlamında Yemek Kültürünün İletişimsel Yönü, International Periodical for the Languages, Literature and History of Turkişh or Turkic, 9(11), 1-16.

Arman, A. ve Ak, S. (2021). Yemek, Kültür ve Turizm Arasındaki İlişkiler, (Editör) Kurnaz, A., Şengül, S.: Gastronomi Turizmi Kavramlar, İlkeler ve Uygulamalar içinde (ss. 1-17) Ankara: Detay Yayıncilik.

Arman, A. ve Şahin Ören, T. (2020). Anadolu Mutfak Kültürünün Unutulmaya Yüz Tutmuş Mısır Unu Bazlı Yemek Örnekleri, (Editör) Küçüktığlı M. S., Seçim Y., Adabalı M. M., Yılmaz M.: Anadolu Mutfak Kültüründen Esintiler içinde (ss.1-18) Konya: Konya Büyükşehir Belediyesi Kültür Yayınları.

Aslan, Z., Güneren, E., ve Çoban, G. (2014). Destinasyon Markalaşma Sürecinde Yöresel Mutfağın Rolü: Nevşehir Örneği, Journal of Tourism and Gastronomy Studies, 2(4), 3-13.

Beşirli, H. (2010). Yemek, Kültür ve Kimlik, Milli Folklor, 22(87), 159-169.

Beşirli, H. (2011). Türk Kültüründe Güç, İktidar, İtaat ve Sadakatin Yemek Sembolizmi Esasında Değerlendirilmesi, Türk Kültürü ve Hacı Bektaş Veli Araştırmaları Dergisi, 38, 139-152.

Boyne, S., Williams, F and Hall, D. R. (2002). On the Trail of Regional Success: Tourism, Food Production and The Isle of Arran Taste Trail, (Editör) Hjalager, A. M. ve Richards, G.: Tourism and Gastronomy içinde (ss. 91-114) Londra: Routledge.

Chang, R. C. Y. and Mak, A. H. N. (2018). Understanding Gastronomic Image from Tourist's Perspective: A Repertory Grid Approach, Tourism Management, (68), 89-100.

Cohen E. and Avieli N. (2004). Food in Tourism: Attraction and Impediment, Annals of Tourism Research, 31, 755-778.

Crompton, J. L., and McKay, S. L. (1997). Motives of Visitors Attending Festival Events, Annals of Tourism Research, 24(2), 425-439.

Cunha, S. (2018). Gastronomic Tourisim a Differential Factor, Millenium, (5), 93-98.

Crewell, J.W. (2020). Nitel Araştırma Yöntemleri: Beş Yaklaşıma Göre Nitel Araştırma ve Araştırma Deseni, (Çev. Ed. Bütün, M. ve Demir, S. B.) 5. Baskı, Ankara: Siyasal Yayınevi.

Çakır, E. (2019). Grup Folkloru Bağlamında İcat Edilmiş Yemek: Satuk Buğra Han Aşı, Akademi Sosyal Bilimler Dergisi, 6 (17), 229-238. 
Çakır, M. U., Şengül, S. ve Parmaksızoğlu, E. (2020). Sinema Perdesinde Gastronomi Görüntüsü: Yemeğin Sosyolojik Yansımaları, Journal of Tourism And Gastronomy Studies, 8(4), 3173-3191.

Çalışkan, O. (2013). Destinasyon Rekabetçiliği ve Seyahat Motivasyonu Bakımından Gastronomik Kimlik, Journal of Tourism and Gastronomy Studies, 1(2), 39-51.

Danhi, R. (2005). Understanding a Culinary Identity to Create Authentic Products for the Marketplace, Asian Restaurant News, February: 40-48.

Fırat, M. (2014). Yemeğin İdeolojisi ya da İdeolojinin Yemeği: Kimlik Bağlamında Yemek Kültürü, Folklor ve Edebiyat, 20(80), 129-140.

Fields, K. (2002). Demand for the Gastronomy Tourism Product: Motivational Factors, (Editör) Hjalager, A.M. ve Richards G.: Tourism and Gastronomy içinde, London: Routledge.

Fox, R. (2007). Reinventing the Gastronomic Identity of Croatian Tourist Destinations, International Journal of Hospitality Management, 26, 546-559.

Gürhan, N. (2017). Toplumsal Değişme ve Yemek Kültürü Üzerine sosyolojik Bir Çözümleme: Mardin Örneği, Uluslararası Sosyal Araştırmalar Dergisi, 10(54), 561-570.

Güzel, G. (2009). Gastronomi ve İnovasyon. İz Atılım Üniversitesi Dergisi, 8, $28-29$

Güzel, B. and Apaydın, M. (2016). Gastronomy Tourism: Motivations and Destinations. (Editör). Avcıkurt, C. Dinu, M. S. Hacıoğlu, N. Soykan, R. E. A. Tetik, N.: Global Issues and Trends in Tourism içinde Sofıa: St. Klıment Ohrıdskı Unıversıty Press.

Hall, C. M., Mitchell, R. and Sharples, L. (2003). Consuming Places: The Role of Food, Wine and Tourism in Regional Development, (Editör) Hall, M., Sharples, L., Mitchell, R., Macionis, N. ve Cambourne, B.: Food Tourism Around the World: Development, Management and Markets, içinde (ss.2559) Oxford: Butterworth-Heinemann.

Hall, C. M., and Mitchell, R. (2005). Gastronomic tourism: Comparing food and wine tourism experiences. In M. Novelli (Ed.), Niche tourism: Contemporary issues, trends and cases (pp. 73-88.). Oxford: Elsevier Butterworth Heinemann.

Harrington, R. J. (2005). Defining Gastronomic Identity, Journal of Culinary Science \& Technology, 4(23), $129-152$.

Harrington, R. J. and Ottenbacher, M. C. (2010). Culinary Tourism - A Case Study of the Gastronomic Capital, Journal of Culinary Science \& Technology, 8(1), 14-32.

Hekimoğlu, G. (2020). Yemek Sosyolojisinin Perspektifinden Gündelik Gurmeler: Batman Örneği, Uluslararası Sosyal Araştırmalar Dergisi, 13(71), 587-599.

Henderson, J C. (2009). Food Tourism Reviewed, British Food Journal, 11(4), 317-326.

Hillel, D., Belhassen, Y. and Shani, A. (2013). What Makes a Gastronomic Destination Attractive? Evidence From the Israeli Negev, Tourism Management, 36, 200-209.

Hjalager A. M. and Richards G. (2002). Still Undigested: Research Issues in Tourism and Gastronomy, (Eds.) Hjalager, A.M. and Richards G.: Tourism and Gastronomy in (ss.207-223) London: Routledge.

Hjalager, A. (2002). A Typology of Gastronomy Tourism, (Eds.) Hjalager, A.M. and Richards G.: Tourism and Gastronomy içinde, London: Routledge 
Hjalager, A. (2004). What Do Tourists Eat and Why? Towards a Sociology of Gastronomy and Tourism, Tourism, 52 (2), 195-201.

Horng, J. S. and Tsai, C. T. (2012). Culinary Tourism Strategic Development: An Asia-Pacific Perspective, International Journal of Tourism Research, 14(1), 40-55.

Horng, J. S. and Tsai, C.T. (2010). Government Websites for Promoting East Asian Culinary Tourism: A Cross-National Analysis, Tourism Management, 31, 74-85.

Ichijo, A. ve Ranta, R. (2018). Yemek ve Ulusal Kimlik, (Çeviren Ataseven, E.), Ayrıntı Yayınları: İstanbul.

İşeri Uzunoğlu, M. (2019). Laura Esquivel, Acı Çikolata (Çeviren Mutlu, H.), Sosyal Bilimler Dergisi, 4 (2).

Karaca, O. B. ve Karacaoğlu, S. (2016). Kültür, Din ve Yemek Etkileşimi Çerçevesinde Arap Mutfağının Kavramsal Olarak İncelenmesi: Adana İli Örneği, Hitit Üniversitesi Sosyal Bilimler Enstitüsü Dergisi, 9(2), 561-584.

Karim, A.S. and Chi, C. G. Q. (2010). Culinary Tourism as a Destination Attraction: An Empirical Examination of Destinations' Food Image, Journal of Hospitality Marketing \& Management, 19: (6), 531555.

Kılıçhan, R. ve Köşker, H. (2015). Destinasyon Markalaşmasında Gastronominin Önemi: Van Kahvaltısı Örneği, Journal of Tourism and Gastronomy Studie, (3), 102-115.

Kim, Y. G., Eves, A. and Scarles, C. (2012). Empirical Verification of a Conceptual Model of Local Food Consumption at a Tourist Destination, International Journal of Hospitality Management, 33, 484489.

Kim, Y.G., Eves, A. and Scarles, C. (2009). Building a Model of Local Food Consumption on Trips and Holidays: A Grounded Theory Approach, International Journal of Hospitality Management, 28, 423-431.

Kivela, J. and Crotts, J.C. (2005). Gastronomy Tourism: A Meaningful Travel Market Segment, Journal of Culinary Science and Technology, 4(2/3), 39-55.

Kivela, J. and Crotts, J.C. (2006). Tourism and Gastronomy: Gastronomy's Influence on How Tourists Experience a Destination, Journal of Hospitality and Tourism Research, 30(3), 354-377.

Kozak, M. (2017). Bilimsel Araştırma: Tasarım, Yazım ve Yayım Teknikleri, 3. Baskı, Detay Yayıncılık.

Köşker, H., Ercan, F. ve Albuz, N. (2018). Osmanlı Çileği'nin Gastronomik Kimlik Unsuru Olarak Değerlendirilmesi, Adıyaman Üniversitesi Sosyal Bilimler Enstitüsü Dergisi, 10(30), 1236-1269.

Küçükaltan, G. (2009). Küreselleşme Sürecinde Gastronomide Yöresel Tatların Turistlerin Destinasyon Tercihlerine ve Ülke Ekonomilerine Etkileri. 3. Ulusal Gastronomi Sempozyumu, 17-18 Nisan, Antalya.

Mak, A. H. N., Lumbers, M., Eves, A. and Chang, R. C. Y. (2012). Factors Influencing Tourist Food Consumption, International Journal of Hospitality Management, 31(3), 928-936.

Mak, A. H. N., Lumbers, M., Eves, A. and Chang, R. C. Y. (2013). An application of the repertory grid method and generalised procrustes analysis to investigate the motivational factors of tourist food consumption, International Journal of Hospitality Management, 35, 327-338.

Merdol, T. K. (2012). Beslenme Antropolojisi 1, Ankara: Hatipoğlu Basım ve Yayın. 
Nebioğlu, O. (2017). Gastronomik Kimlik ve Gastronomik Turizm Ürünlerinin Sınıflandırılması Üzerine Nitel Bir Araştırma: Alanya Örneği, Journal of Tourism and Gastronomy Studies 5(2), 39-60

Nebioğlu, O. (2018). Turistlerin Yemek Tüketim Davranışları Üzerine Kavramsal Bir Değerlendirme. Turizm Akademik Dergisi, 5(1), 124-136.

Okumus, B., Okumus, F. and McKercher, B. (2007). Incorporating Local and International Cuisines in the Marketing of Tourist Destinations: The Cases of Hong Kong and Turkey, Tourism Management, $28,253-261$.

Ondieki, E. B., Kotut, E. J. Gatobu, C. K. and Wambari, E. M. (2017). Gastronomic Identity: Role of The Environment and Culture on Culinary Tourism, African Journal of Tourism, Hospitality and Leisure Studies, 3(1), 17-21.

Quan, S. and Wang, N. (2004). Towards A Structural Model of The Tourist Experience: An Illustration from Food Experiences in Tourism, Tourism Management, 25(3), 297-305.

Rao, H., Monin, P. and du Rand, R. (2003). Institutional Change in Toque Ville: Nouvelle Cuisine as An Identity Movement in French Gastronomy, The American Journal of Sociology, 108(4), 795-843.

Sağır, A. (2012). Bir Yemek Sosyolojisi Denemsi Örneği Olarak Tokat Mutfağı̆, International Periodical for The Languages, Literature and History of Turkişh or Turkic, 7(4), 2675-2695.

Samanc1, Ö. (2012). Avrupa'da ve Türkiye'de Yemek Tarihçiliğine Kısa Bir Bakış. Yemekte Tarih Var Yemek Kültürü ve Tarihçiliği, (Der.) Ayşegül Avcı, Seda Erkoç ve Elvin Otman, E.: İstanbul: Tarih Vakfı Yurt Yayınları

Selimoğlu, E. ve Gültekin, T. (2018). Laura Esquivel'in Acı Çikolata Romanı Üzerinden Duygusal Dünya ve Yemek Kültürü İlişkisi, Antropoloji, (36), 71-85.

Sevindik, A. (2017). Türk Halk Kültüründe Yemek ve Cinsiyet İlişkisi, Dede Korkut Uluslararası Türk Dili ve Edebiyatı Araştırmaları Dergisi, 6(13), 611-637.

Sparks, B., Bowen, J. and Klag, S. (2003). Restaurants and the Tourist Market, International Journal of Contemporary Hospitality Management, 15 (1), 6-13.

Stajcic, N. (2013). Understanding Culture: Food as a Means of Communication. Hemispheres, 28, 5-14.

Şahin, G. G. ve Ünver, G. (2015). Destinasyon Pazarlama Aracı Olarak "Gastronomi Turizmi”: İstanbul'un Gastronomi Turizmi Potansiyeli Üzerine Bir Araştırma, Journal of Tourism and Gastronomy Studies, 3(2), 63-73.

Şahin Ören, T. ve Ören, V. E. (2020). Gastronomi Turizmi Kapsamında Sürdürülebilir Bir Değer: Paklo Örneği ve Reçete Uygulaması, (Editör) İmik Tanyıldızı, N.; Durgun Şahin, Y.: Güncel Sosyal Bilimler Arastırmaları II içinde (ss.135-146) Ankara: Akademisyen Kitabevi.

Şanlıer, N. (2005). Yerli ve Yabancı Turistlerin Türk Mutfağı Hakkındaki Görüşleri, Gazi Eğitim Fakültesi Dergisi, 25(1), 213-227.

Tekindal, M. ve Uğuz Aksu, Ş. (2020). Nitel Araştırma Yöntemi Olarak Fenomenolojik Yaklaşımı ve Kapsamı ve Sürecine Yönelik Bir Derleme, Ufkun Ötesi Bilimsel Dergisi 20(1), 153-182.

Utanır, A. (2019). Antep Kimliğinin Yeniden İnşasında Mutfağın Rolü, Yayınlanmamış Doktora Tezi, Ankara Üniversitesi Sosyal Bilimler Enstitüsü Sosyoloji Anabilim Dalı, Ankara. 
Wolf, E. (2006). Culinary Tourism: The Hidden Harvest, Dubuque, IA: Kendall/Hunt Publishing Company. 